\title{
Prevalence of headaches in individuals referred from primary care to secondary care
}

\author{
Prevalência de cefaleia em indivíduos encaminhados da atenção \\ primária para a secundária
}

\author{
Joismar Manuel Rodrigues', Vanessa Vilela Caires', Kátia Beatriz Costa Fontoura', \\ Teresa Cristina Santos Silva', Simone Fonseca Goulart', Cláudia Marcucci Rocha', Antônio Lúcio Teixeira², \\ Ariovaldo Alberto da Silva Junior \\ 'Universidade José do Rosário Vellano - Unifenas, Belo Horizonte, MG, Brazil \\ ${ }^{2}$ Faculdade de Ciências Médicas, Belo Horizonte, MG, Brazil \\ Rodrigues JM, Caires W, Fontoura KB, Silva TC, Goulart SF, Rocha CM, Teixeira AL, Silva Junior AA \\ Prevalence of headaches in individuals referred from primary care to \\ secondary care. Headache Medicine. 2011;2(4):200-3
}

\begin{abstract}
Background: Improve the quality of public health is a growing necessity today. Identifying reasons for medical referral (from general to specialized care) is a prelude for developing educational initiatives that have this goal. Objective: To estimate the prevalence of headaches as a cause of referral from the primary to the secondary level of public medical care. Methods: First-time referrals from four primary care units to neurology care were assessed. Results: Sample consisted of 587 individuals referred to neurology consultation. Headache was the cause of referral in $31.2 \%$ of the individuals; $79.2 \%$ of the headache cases were in women. Rates for other diseases were lower and are presented for benchmarking. Conclusion: Headache represented an important cause of demand for neurological care. Education initiatives on principles of headache management are necessary and may translate into decreased referral rates to neurologists.
\end{abstract}

Keywords: Headache; Primary health care; Secondary health care

\section{RESUMO}

Introdução: Melhorar a qualidade da saúde pública é uma necessidade crescente nos dias atuais. Identificar os motivos de encaminhamento médico (da atenção generalista para a especializada) é um prelúdio para o desenvolvimento de iniciativas educacionais que tenham este objetivo. Objetivo: Estimar a prevalência de cefaleias como causa de encaminhamento do nível primário para o secundário, de assistência médica, na saúde pública. Métodos: Num primeiro mo- mento, os encaminhamentos de quatro unidades de atenção primária para a atenção neurológica foram avaliados. Resultados: A amostra consistiu em 587 indivíduos referenciados para consulta em neurologia. Cefaleia respondeu por $31,2 \% ; 79,2 \%$ dos casos de cefaleia foram em mulheres. As porcentagens de outros motivos de atendimento foram mais baixas e são apresentadas para comparação. Conclusão: Iniciativas educacionais voltadas para o manejo das cefaleias são necessárias e podem resultar na diminuição das taxas de encaminhamento para neurologistas.

Palavras-chave: Dor; Cefaleia; Ocitocina; Síndrome do túnel do carpo

\section{INTRODUCTION}

The Brazilian Public Health System (PHS) provides universal medical access to the population. It is structured in three levels of care. The primary care consists of basic health units (BHUs), being the typical "entry door" into the system. (1) It accounts for the preventive care, as well as for treatment (by family physicians or general practitioners). An important component of the primary care in the PHS is the family heath program (FHP), which mainly focuses on preventive and educational health strategies. A recent study demonstrated that $85 \%$ of the families seeking medical care in the PHS do it so trough the $\mathrm{FHP}^{(2)}$ which is largely 
responsible for referrals to the secondary level of care. The secondary care consists of specialty clinics, and patients are to be referred by the primary care doctors into this level. ${ }^{(2)}$ The tertiary care consists of subspecialty and high complexity hospitals. It has been suggested that a considerable proportion of referrals to the secondary neurological care is due to headaches. ${ }^{(3)}$

The Brazilian PHS follows the structural recommendations of the World Health Organization (WHO) to the BRIC countries (Brazil, Russia India and China). ${ }^{(4,5)}$ The system seems to be effective in providing primary care, ${ }^{(6)}$ and important successes are reported in the control of diabetes and hypertension. ${ }^{(7,8)}$ Nonetheless, headaches have not deserved specific recommendations from a public health perspective. ${ }^{(9)}$ As a consequence, unnecessary referrals to the secondary care may exist. ${ }^{(10-}$ 12) The problem is further amplified by the recognized difficulties in establishing a headache diagnosis at the primary care level. ${ }^{(13,14)}$

In the present study was assessed the prevalence of headaches among patients referred from the primary care system to a secondary neurology program.

\section{METHODS}

This study was conducted at subdistrict north of Belo Horizonte, the capital of Minas Gerais state, Brazil. Through the FHP, this subdistrict attends 193,764 inhabitants. It is structured into 19 primary care centers and one secondary unit as main referral.

Patients should first be attended by general practitioners. Patients in need of neurological care are referred to secondary care units. Accordingly, in this study we assessed reasons for referral from four primary care units that can only refer patients to a secondary care center.

The study was conducted from January of 2007 to September of 2009. For referred patients we collected demographic variables (gender, age) and reasons for referral as follows: headache, epilepsy, fainting, Alzheimer's disease, dementia or other memory problems, Parkinson's disease and tremors, strokes, and other causes. We restricted our analyses to adults (17 or older).

Extracted data were entered into Epiinfo (version 3.5.1) and description of results was performed.

The study was approved by the Ethics Committee of the University of José do Rosário Vellano (CEP/Unifenas) and the Ethics Committee on Public Health Research, Belo Horizonte (CEP/SMSA/BH).

\section{RESULTS}

Of 587 referrals, 183 were secondary to headaches. Accordingly, headaches responded by $31.2 \%$ of the referrals. Of headache patients, $79.2 \%$ were women with a mean age of 40 years $(S D=2)$.

Other causes of referrals are described in Table 1. The second most common cause of referral was epilepsy and related syndromes (14.9\%) followed by fainting (5.6\%) and Alzheimer's disease and memory problems (5.3\%). With regard to median age stratified by category the average age was 38.5 years in epilepsy followed by 53 years for fainting and 72 years for Parkinson's disease. This information can be seen in Table 2 .

\begin{tabular}{|c|c|c|c|c|c|c|}
\hline \multirow[t]{3}{*}{ Category } & \multicolumn{4}{|c|}{ Gender } & \multirow[t]{3}{*}{ Total } & \multirow[t]{3}{*}{$\%$} \\
\hline & \multicolumn{2}{|c|}{ Men } & \multicolumn{2}{|c|}{ Women } & & \\
\hline & $n$ & $\%$ & $\mathrm{n}$ & $\%$ & & \\
\hline Headache & 38 & $20.8 \%$ & 145 & $79.2 \%$ & 183 & 31.2 \\
\hline Epilepsy and related syndromes & 45 & $51.1 \%$ & 43 & $48.9 \%$ & 88 & 14.9 \\
\hline Fainting & 10 & $30.3 \%$ & 23 & $69.7 \%$ & 33 & 5.6 \\
\hline Parkinson's disease and Tremors & 8 & $36.4 \%$ & 14 & $63.6 \%$ & 22 & 3.7 \\
\hline $\begin{array}{l}\text { Alzheimer's disease and memory } \\
\text { problems }\end{array}$ & 7 & $22.6 \%$ & 24 & $77.4 \%$ & 31 & 5.3 \\
\hline Stroke & 9 & $52.9 \%$ & 8 & $47.1 \%$ & 17 & 2.9 \\
\hline Others* & 83 & $42.6 \%$ & 112 & $57.4 \%$ & 195 & 33.2 \\
\hline Unknown & 9 & $50.0 \%$ & 9 & $50.0 \%$ & 18 & 3.0 \\
\hline Total & 209 & & 378 & & 587 & 100 \\
\hline
\end{tabular}

*Include: regional pain syndromes, polineuropathies, carpal tunnel syndrome and others. 


\begin{tabular}{lccc}
\multicolumn{4}{l}{ Table 2 - Reasons for referral to neurological care stratified by age } \\
\hline \multicolumn{1}{c}{ Category } & Minimum & Median & Maximum \\
\hline Headache & 17.0 & 39.0 & 73.0 \\
Epilepsy and related syndromes & 18.0 & 38.5 & 75.0 \\
Fainting & 18.0 & 53.0 & 92.0 \\
Parkinson's disease and Tremors & 36.0 & 72.0 & 90.0 \\
Alzheimer's disease and memory problems & 38.0 & 72.0 & 86.0 \\
Stroke & 27.0 & 56.0 & 85.0 \\
Others* & 18.0 & 50.0 & 87.0 \\
Unknown & 19.0 & 51.0 & 76.0
\end{tabular}

*Include: regional pain syndromes, polineuropathias, carpal tunnel syndrome and others

\section{DISCUSSION}

Headache was the main cause of referrals for neurological care. With regard to age, headache and epilepsy were the most frequent among young adults and Alzheimer's disease and Parkinson's disease affected more the elderly.

These results come at little surprise, since findings are supported by the literature which suggests that headache responds for around one third of referrals to neurological care. ${ }^{(3)}$ The relative frequency of referrals due to headaches is particularly expressive when contrasted to other reasons. For instance, epilepsy responded to less than half of the headache referrals. Parkinson's disease responded by only $3.7 \%$.

The expressive frequency of referrals due to headaches has several potential explanations. First, the prevalence of headaches in the population is far higher than the prevalence of other neurological disorders. However, since headaches are diagnosed based on clinical grounds and are benign in most cases, this fact alone unlikely explains the high proportion of referrals. According to Galdino et al., ${ }^{(14)}$ the lack of dissemination of diagnostic criteria for headaches among primary care doctors is associated with reduced comfort in assigning headache diagnoses and may explain the referrals. ${ }^{(15)}$ Indeed, according to Vincent and Carvalho, ${ }^{(16)}$ only $44.9 \%$ of the migraine cases seen by primary care doctor in Brazil received a proper diagnosis.

Our study has clear limitations. The most important is the lack of specific headache diagnoses, since we relied on information obtained from the referral letters. Second, our data may not be generalizable to other regions. We aim to repeat this study after these educational initiatives are conducted, in order to test the hypothesis that referral rates will be reduced.
Accordingly, we demonstrated that high proportion referrals to neurological cares are due to headaches in the PHS. This may reflects the high prevalence of headaches in the population, but also the ineffectiveness of the primary care system in dealing with headaches. Educational initiatives are to be created and tested in order to change this paradigm.

\section{REFERENCES}

1. Malta DC, Santos FP. O Programa de Saúde da Família (PSF) e os modelos de assistência à saúde no âmbito da reforma sanitária brasileira. Revista Médica de Minas Gerais. 2003; 13(4):251-9.

2. Giovanella L, de Mendonça MH, de Almeida PF, Escorel S, Senna M de C, Fausto MC, et al. Family health: limits and possibilities for an integral primary care approach to health care in Brazil. Cien Saude Colet. 2009;14(3):783-94. [Article in English, Portuguese]

3. Ferri-de Barros JE, Nitrini R. [Which patients does the neurologist assist? Basis for a curriculum in neurology]. Arq Neuropsiquiatr. 1996; 54(4):637-44.

4. Steiner TJ. Lifting the burden: The global campaign to reduce the burden of headache worldwide. J Headache Pain. 2005;6(5): 373-7.

5. Martelletti P, Haimanot RT, Láinez MJ, Rapoport AM, Ravishankar K, Sakai F, et al. The Global Campaign (GC) to Reduce the Burden of Headache Worldwide. The International Team for Specialist Education (ITSE). J Headache Pain. 2005;6(4):261-3.

6. Escorel S, Giovanella L, Magalhães de Mendonça MH, de Castro Maia Senna M. The Family Health Program and the construction of a new model for primary care in Brazil. Rev Panam Salud Publica. 2007;21 (2-3):164-76. [Article in Portuguese].

7. de Paiva DC, Bersusa AA, Escuder MM. Healthcare assessment for patients with diabetes and/or hypertension under the Family Health Program in Francisco Morato, São Paulo, Brazil. Cad Saude Publica. 2006;22(2):377-85.

8. Carvalho BG, Souza RKT, Soares DA, Yagi MCN. Diseases of the circulatory system before and after the Family Health Program, Londrina, Paraná. Arq Bras Cardiol. 2009;93(6):597-601, 64550. [Article in English, Portuguese]. 
9. Junior AS, Krymchantowski A, Moreira P, Vasconcelos L, Gomez $\mathrm{R}$, Teixeira A. Prevalence of headache in the entire population of a small city in Brazil. Headache. 2009;49(6):895-9

10. Kowacs PA, Twardowschy CA, Piovesan EJ, Dal-Prá Ducci R, Cirino RH, Hamdar F, et al. General practice physician knowledge about headache: evaluation of the municipal continual medical education program. Arq Neuropsiquiatr. 2009;67(3A):595-9.

11. Bigal ME, Bordini CA, Speciali JG. Etiology and distribution of headaches in two Brazilian primary care units. Headache. 2000; 40(3):241-7.

12. Bigal ME, Bigal JO, Bordini CA, Speciali JG. Prevalence and costs of headaches for the public health system in a town in the interior of the state of São Paulo. Arq Neuropsiquiatr. 2001; 59(3A): 504-11.

13. Gantenbein AR, Sándor PS. Physiological parameters as biomarkers of migraine. Headache. 2006;46(7):1069-74.

14. Galdino GS, Paz e Albuquerque TI, Medeiros JLA. Primary headaches: a diagnostic approach by non-neurologist doctors. Arq Neuropsiquiatr. 2007;65(3A):681 -4. [Article in Portuguese].

15. Khu JV, Siow HC, HO KH. Headache diagnosis, management and morbidity in the Singapore primary care setting: findings from a general practice survey. Singapore Med J. 2008;49 (10):774-9.

16. Vincent MB, Carvalho JJ. Primary headache care delivery by nonspecialists in Brazil. Brazilian Headache Care Cooperative Group. Cephalalgia. 1999;19(5):520-4.

Received: 1/30/2011

Accepted: $11 / 25 / 2011$

\section{Correspondence}

Ariovaldo Alberto da Silva Junior, MD Rua Bernardo Guimarães, 2154, apto. 501 - Lourdes Belo Horizonte, MG., Brazil juniorariovaldo@uol.com.br 